\title{
Social Innovation for Work Inclusion - Contributions of Swedish Third Sector Organizations'
}

I Malin Lindberg ${ }^{2}$

Professor in Gender and Technology, Luleå University of Technology, Sweden

I Johan Hvenmark

Associate Professor in Business Administration, Marie Cederschiöld University, Sweden

I Cecilia Nahnfeldt

Associate Professor in Gender Studies, Uppsala University, Sweden

\begin{abstract}
The innovative contributions of third sector organizations (TSOs) to tackle work-related societal challenges are increasingly acknowledged in policy and research, but rarely in Nordic working life studies. The article helps fill this knowledge gap by an empirical mapping of efforts by Swedish TSOs to promote work inclusion among people considered disadvantaged in the regular labor market, due to age, disabilities, origin, etc. Previous studies of social innovation help distinguish their innovativeness in terms of alternative or complementary ways to perceive and promote work inclusion in regard to Swedish labor market policies. By combining various measures for providing and preparing work opportunities, addressing their participants through individualistic and holistic approaches, and managing work inclusion by varying organization, funding, and alliances, the mapped cases seem to innovatively compensate for government and market failures in the work inclusion domain to some extent, while also being limited by their own voluntary failures.
\end{abstract}

\section{KEYWORDS}

Civil society / labor market / social enterprise / social innovation / third sector / work inclusion

\section{Introduction}

(X) wasn't good enough for Samhall. Now she runs a social enterprise for people who have been sorted out. The Swedish Agency for Public Management (Statskontoret) sounded the alarm several years ago - the wrong people were sent to Samhall. But nothing has happened (...) people with disabilities end up outside the working life. (Dagens Arbete, 20 April 2021) ${ }^{1}$

his lead paragraph of a press article illustrates the debate that raged in Swedish media in the spring of 2021 regarding the perceived problems with 'cream skimming' in the state-owned company Samhall, which is Sweden's main provider of sheltered employment for people with reduced working capacity due to disabilities of some kind. A series of articles $^{2}$ and an investigative TV-program ${ }^{3}$ argued that Samhall's mission was compromised by prioritizing people with too little or the wrong type of disability in

\footnotetext{
${ }^{1}$ You can find this text and its DOI at https://tidsskrift.dk/njwls/index.

${ }^{2}$ Corresponding author: malin.lindberg@ltu.se.
} 
order to fulfill their profit requirements. This was contrasted with the supposedly more inclusive work opportunities provided by work integration social enterprises (WISE), ${ }^{4}$ while operating under less beneficial economic circumstances than Samhall. As pointed out in the quote, this is not a new issue - since Samhall was established in 1980 it has been recurrently criticized for similar reasons by public authorities, media and researchers (e.g., Skedinger \& Widerstedt 2007).

The issue at heart of this media debate relates to a broader debate on how to promote social inclusion among those most stricken by current societal challenges of unemployment, poverty, ill-health, and segregation, and which societal actors are best placed to help do this. Sharpened requirements and conditions on the Nordic labor market contribute to these challenges, by disqualifying more and more people from employment and self-provision. Youth, immigrants, and people with disabilities or ill-health are perceived to be particularly disadvantaged in regard to the regular labor market, according to statistics and research (Gustafsson et al. 2018; Hobbins 2016; Wikström \& Ahnlund 2018). Novel measures are called for in order to promote work inclusion among these groups, since current welfare and employment services are considered insufficient (Lindberg et al. 2018). An increasingly common term for such measures is 'social innovation', which refers to the development and implementation of novel methods, services, alliances, etc, for improving peoples' living conditions, in terms of their well-being, inclusion and empowerment (ibid).

The cross-boundary character of societal challenges means that social innovation engages actors from all societal sectors (Butzin \& Terstriep 2018). Organizations from the civil society - including WISE and other types of voluntary associations, cooperatives, foundations, and religious communities - have nevertheless been claimed to be 'best placed to produce social innovation, outperforming business firms and state agencies in this regard' (Anheier et al. 2019, p. 2). This is derived from their freestanding position as a 'third sector' in society, besides the public and private sectors, which makes them well positioned to identify and address unmet needs of improved social inclusion. The innovative contributions of third sector organizations (TSOs), as they are referred to in this article, to tackle work-related societal challenges are increasingly discussed in social innovation studies (Anheier et al. 2019; Lindberg 2021). They are, however, rarely addressed in Nordic working life studies, except for trade unions, in favor of the private and public sectors (see, e.g., Bakker et al. 2015; Hvid et al. 2011).

This article aims to help fill the knowledge gap concerning TSOs in Nordic working life studies, by providing empirical insights into efforts by Swedish TSOs to innovatively promote work inclusion among disadvantaged groups. This is achieved through a mapping of contemporary empirical cases, by means of a multiple case study approach. The main research question addressed in this article is: How do Swedish TSOs contribute to tackle work-related societal challenges through innovative efforts for work inclusion? Previous studies of social innovation help distinguish the TSOs' innovativeness in this domain, in terms of alternative or complementary ways to perceive and promote improved inclusion, empowerment, and wellbeing. The article thereby adds to previous studies of efforts for work inclusion among various disadvantaged groups in the Nordic working life, including a series of articles published in Nordic Journal of Working Life Studies, where TSOs or social innovation rarely are discussed (see, e.g., Boulus-Rødje 2019; Bredgaard \& Thomsen 2018; Wikström \& Ahnlund 2018). 
Three more detailed questions guide the article: What efforts are made by Swedish TSOs to promote work inclusion among disadvantaged groups? What characterizes these efforts, in terms of their measures, venues, management, participants, and other stakeholders? In what sense are these efforts innovative regarding how they tackle work-related societal challenges? The article is initiated by an overview of previous studies, followed by an account of methods and materials, as well as a presentation of the empirical results. Finally, the results are discussed and conclusions are drawn in the light of previous studies.

\section{Theoretical framework}

This section presents a theoretical framework for how we in later sections distinguish the innovativeness in how TSOs tackle work-related societal challenges. The framework is based on findings from studies of social innovation, work inclusion and the third sector.

\section{Social innovation and the third sector}

Social innovation is increasingly studied in the Nordic context and elsewhere, as a means for tackling persistent societal challenges of unemployment, poverty, ill-health, segregation, etc. (Anheier et al. 2019; Lindberg et al. 2018). This includes studies of the development and implementation of novel methods, services, alliances, etc, which are social in both their aims and means. That they are 'social in their aims' implies that the primary purpose of social innovations is to improve peoples' living conditions in terms of inclusion, empowerment, and wellbeing. That they are 'social in their means' implies that social innovations are developed through collaborative processes, with new social relations, practices, and structures. Empowerment of disadvantaged groups is typically strived for in social innovation, in the sense of improving people's agency to impact the society and their own lives. In order to bridge organizational and sectorial drainpipes when tackling cross-boundary challenges, multi-actor mobilization is considered crucial in social innovation (ibid). The same goes for multilevel mobilization, in order to address the individual, organizational and societal dimensions of such challenges. A global study of social innovations finds that TSOs and public authorities are most frequently engaged, followed by private companies (Butzin \& Terstriep 2018). The target groups are also recurrently involved, in order to empower them through the process.

Since many TSOs have a tradition of civic engagement and social needs orientation, they are considered to be well equipped to develop social innovations (Anheier et al. 2019; Lindberg 2021; Lindberg \& Nahnfeldt 2017a, 2017b). In the Nordic countries, TSOs generally engage citizens through leisure activities, membership, volunteering, fundraising, or employment in a wide range of areas such as culture, sports, health, social services, adult education, and human rights (Henriksen et al. 2019; von Essen \& Svedberg 2020). A study of European cases concludes that TSOs engage both employees and volunteers in the generation and implementation of social innovations, where the motivation and commitment of volunteers help identify new social needs and introduce novel ways of thinking and working (de Wit et al. 2019). The established roles of many TSOs as voice-bearers for disadvantaged groups and advocacy actors for citizen 
interests enforce their innovativeness, by enabling to them to identify and address unmet and neglected needs of improved social inclusion (Anheier et al. 2019; Lindberg 2021). Their innovativeness is also derived from their role as welfare service providers in the domains of employment, rehabilitation, social work, education, etc.

The Nordic welfare model has traditionally implied that public authorities are the main providers of welfare services, while TSOs mainly are ascribed a complementary role (Anheier et al. 2019; Wijkström \& Zimmer 2011). This 'societal contract' of sectorial work division was, however, preceded by a historical period where Swedish TSOs developed several of the welfare services that were later incorporated in the public sector, such as childcare, homecare, homeless shelters, and nursing education (Lindberg 2021; Meeuwisse 2008). They have thereafter continued to develop social innovations to compensate for 'government failure' by better addressing heterogenous preferences among minorities than public sector actors, as well as for 'market failure' by better signaling trustworthiness than what private companies are able to due to profit-seeking interests and limited monitoring (Anheier et al. 2019; Steinberg 2006). During the last decades, the societal contract in the Nordic welfare model has been incrementally challenged and changed, with increased delegation of welfare services provision from public authorities to private companies and to some extent to TSOs (Kamp et al. 2013; Wijkström \& Zimmer 2011).

In Sweden, TSOs make up only a few percent of the contracted providers of public welfare services. Their added value in this domain - in terms of innovativeness and social needs orientation - is nevertheless underlined by policymakers and national interest organizations of TSOs (Lindberg 2021; Meeuwisse 2008). The growth of TSOs' service provision in Swedish welfare is actively supported through public policy initiatives, national campaigns and novel forms for cross-sectorial contracts and partnerships, for example, idéburet offentligt partnerskap (IOP). Studies conclude, however, that the assumed innovativeness of Swedish TSOs varies in practice, due to internal and external factors (Lindberg 2021; Lindberg \& Nahnfeldt 2017b). It is, for example, dependent on internal support and resources for developing new solutions alongside the organizations' established operations. It is also dependent on regulations of public subsidies, such as timelimited and earmarked project funding. The term 'voluntary failure' has been used for describing TSOs' recurrent difficulties to organize and finance long-term implementation and operation of novel solutions (Steinberg 2006). Studies conclude that cross-sectorial cooperation may help compensate for this failure, while far-reaching compromises may delimit the TSOs' innovative position as a freestanding sector in society (Lindberg 2021).

\section{Innovative work inclusion}

Innovation is recognized as 'a promising new focus' in Nordic working life studies (Bakker et al. 2015, p. 35). It is argued that the very essence of working life research is changes in work and its effect on innovation, health, and qualifications (Hvid et al. 2011). Innovation is most commonly addressed in terms of technological progress, workplace development, employee participation, and changes in labor market relations, in this research field (e.g., Alasoini 2011; Bakker et al. 2015; Hvid et al. 2011). Innovation is further discussed primarily in regard to the public and private sectors, with few references to the third sector, except for trade unions. Innovative work inclusion as a means to tackle societal challenges of unemployment, poverty, segregation, and 
ill-health is, on the other hand, increasingly addressed in social innovation studies (e.g., Leca et al. 2019; Lindberg et al. 2018; Oeij et al. 2018). This includes, for example, novel approaches to integrate employment and educational training through work-oriented education and life counseling, new cross-sector partnerships to jointly create inclusive work opportunities, WISE as a means for pursuing commercial trade for work integration purposes, as well as The European Social Fund's promotion of social innovation for work inclusion (Leca et al. 2019; Lindberg et al. 2018; Oeij et al. 2018).

Studies that explicitly align the topics of innovation, work inclusion and the third sector argue that innovation, in this context, is best understood in terms of novel methods and approaches in welfare domains such as employment, health, and education (e.g., Brimhall 2019; Kapoor et al. 2018). It is demonstrated that innovations in these domains can either be studied per se (e.g., Andreassen et al. 2020) or as an outcome of other factors, such as an encouraging work environment (e.g., Brimhall 2019). It is argued that innovative work inclusion can be understood both in regard to employees inside an organization or to the community outside an organization (Brimhall 2019; Fujimoto et al. 2019). Innovative work inclusion is primarily discussed in regard to certain disadvantaged groups (e.g., Lysaght et al. 2012), employees (e.g., Brimhall 2019), or local community members (Fujimoto et al. 2019). Work inclusion is also studied in regard to labor market policy, employment services, or educational training (e.g., Andreassen et al. 2020; Kapoor et al. 2018). It is underlined that work inclusion can be understood as a subjective matter of individuals' own experiences, as well as an objective matter of how they are actually treated by others in organizations (Brimhall 2019; Lysaght et al. 2012). The role of TSOs in innovative work inclusion is sometimes studied as such (e.g., Brimhall 2019), sometimes as part of wider stakeholder alliances (e.g., Kapoor et al. 2018) and sometimes as intermediaries between different societal sectors (e.g., Fujimoto et al. 2019). It is concluded that work inclusion may be enhanced by innovative mobilization and alliances across organizational and sectorial boundaries (e.g., Andreassen et al. 2020; Kapoor et al. 2018).

Patterns and mechanisms of exclusion and inclusion in the working life is a recurrent topic in Nordic working life studies. This concerns, for example, barriers, enhancers, and measures for labor market entrance among groups who are considered particularly disadvantaged in the regular labor market, due to age, disabilities, ill-health, origin, etc (Bakker et al. 2015). Swedish employment programs for improved work inclusion are recurrently studied in the form of (Gustafsson et al. 2018; Hobbins 2016; Skedinger \& Widerstedt 2007; Wikström \& Ahnlund 2018):

- Subsidized employment - where the government compensates part of the employer's wage costs when employing people with reduced working capacity

- Supported employment - with on-the-job support to individuals by personal job coaches

- Sheltered employment - where people with work disabilities are offered adapted work opportunities in protected environments

Even if these programs are all publicly funded, they are carried out by actors from all societal sectors, including governmental agencies, municipalities, the state-owned company Samhall, private companies and TSOs. Studies of these programs recognize that Swedish labor market policies have increasingly applied 'the work strategy' (arbetslinjen) to promote a more or less mandatory participation in paid labor for all adults 
since the turn of the millennium (Wikström \& Ahnlund 2018). The strategy is based on 'the work first approach', where work and activation are seen as the principal way to tackle societal challenges such as poverty, ill-health, segregation, etc. This is enforced by mandatory participation in employment programs offered by The Swedish Public Employment Service (Arbetsförmedlingen), tightened eligibility criteria to welfare support and benefit cuts, in lieu of social and economic redistribution through the public insurance system. Despite more and more people being disqualified from employment and self-provision due to sharpened qualification requirements and working conditions, these policies seem to transfer the responsibility for inclusion from the society to the individual, as part of a gradual shift from explaining unemployment by 'lack of employment' in organizations and society to 'lack of employability' among individuals (ibid).

Questions have been raised regarding how the prospects for improved work inclusion among youth, immigrants and people with disabilities are affected by the division of responsibilities in this domain not only between individuals and the society, but also between actors from different societal sectors (Gustafsson et al. 2018; Hobbins 2016; Wikström \& Ahnlund 2018). The role of third sector actors has mainly been discussed in regard to WISE and cross-sector partnerships in social innovation studies (Leca et al. 2019; Oeij et al. 2018) and in regard to professionalization and organizational management in civil society studies (Hvenmark 2013, 2016). It is concluded that TSOs are increasingly run by paid employees rather than unpaid volunteers, despite their long tradition of combining employment and volunteering in their operations (Jutterström et al. 2018; Selander \& Ruuskanen 2016). Surveys reveal that employees in Swedish TSOs find their work to be more meaningful, free, and flexible than in the private or public sector, while the working conditions, wage levels, and career opportunities are considered to be poorer (Jutterström et al. 2018; Unionen 2016). The surveys also reveal that the workforce of Swedish TSOs often is rather homogenous, with a majority of university-educated, middle-aged, white women among their employees and volunteers.

\section{Methods and materials}

This article presents the results of an explorative mapping of contemporary empirical cases of efforts to promote work inclusion by Swedish TSOs. The mapping was carried out as part of a multi-disciplinary research project, that aims to advance the knowledge on how Swedish TSOs contribute to an inclusive and diverse working life through social innovation. A multiple case study approach was used in the mapping, where several empirical cases are mapped and examined simultaneously on an overarching level. This approach was chosen in order to provide a tentative overview of how TSOs' work inclusion efforts are manifested. Case studies are considered rewarding when exploring contemporary phenomena in real-life contexts where the relevant variables are manifold (Yin 2009). Multiple case studies specifically provide a multifaceted overview of the studied phenomenon, by distinguishing a spectrum of characteristics. The intention of the chosen approach was, thereby, not to pursue an in-depth investigation of individual cases. Neither was the intention to systematically compare the cases among themselves or in regard to other societal sectors, as in a comparative case study approach. Such intentions may instead be subject to further studies, based on the findings in this article.

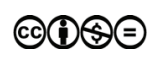


The case selection in the mapping was based on relevance rather than randomness in regard to each of these three criteria:

- Efforts that aim to innovatively promote work inclusion among disadvantaged groups

- Efforts managed by Swedish TSOs, that is, voluntary associations, cooperatives, foundations, and religious communities

- Efforts that are new in the sense that they have not been tried before by the organization or among its target groups

The ambition was to identify a variety of cases within these criteria, in regard to their measures, venues, management, participants, and other stakeholders. This included an ambition to identify cases managed by a variety of TSOs, in order to overview the issue in regard to the third sector as a whole. In order to achieve this variety, cases were identified through a combination of open calls, stakeholder dialogues, web browsing, and previous studies. Open calls for potential cases were made via newsletters, social media, and conferences, targeting Swedish TSOs and other stakeholders. Online records and previous studies were also browsed in order to identify additional examples.

The mapping resulted in 75 cases $^{5}$ that met the criteria, overviewed in Table 1 . The number of mapped cases and their numerical distribution are not to be seen as representative for all existing cases in Sweden, since a complete listing was not the intention of the presented study and would also be difficult to achieve for methodological reasons. For example, the vast number of denominations and synonyms for TSOs, work inclusion, and innovation make it difficult to systematically identify cases through web searches.

Table I Overview of mapped cases

\begin{tabular}{ll}
\hline & Mapped cases (75 in total) \\
\hline Organization type & Voluntary association: 54 \\
& Cooperative: 9 \\
& Foundation: 8 \\
& Religious community: 4 \\
\hline Participants $^{\mathbf{6}}$ & Immigrants: 36 \\
& Youth: 20 \\
& People with disabilities: 17 \\
& People with ill-health: 17 \\
& People with addiction: 6 \\
& Homeless: 3 \\
& Others: 12 \\
\hline Measures $^{\mathbf{7}}$ & Employment: 4 I \\
& Internship: 33 \\
& Work training: 32 \\
& Educational training: 27 \\
& Matchmaking: I5 \\
Entrepreneurship: 9 \\
Volunteering: 8 \\
Mentorship: 5 \\
\hline Pimeframe & Permanent establishments: 55 \\
& Temporary projects: 20 \\
\hline
\end{tabular}


Document studies were used as the main method for data collection in the mapped cases. This method was chosen in order to achieve an overview of the cases' main characteristics, in terms of their measures, venues, management, participants, and other stakeholders. It encompassed collection and review of written material in the form of website descriptions and public reports, for example, project descriptions. These were collected from the cases' official websites and e-mail correspondence with the managing organizations. The data collected through document studies was analyzed by means of an abductive approach in the sense that both the data and the theory informed the analysis in a cumulative manner. This helped identify and systematize empirical contents regarding the above-mentioned characteristics in relation to the theoretical framework of social innovation in relation to work inclusion and the third sector, provided by previous studies. The results from the document studies provide the main basis for the empirical accounts presented in the subsequent section. In order to complement the document studies with more detailed data, semi-structured qualitative interviews were carried out with representatives from nine of the mapped cases, overviewed in Table 2. These were selected based on their estimated ability to provide more insights into the various characteristics of TSOs' work inclusion efforts. Transcribed versions of recorded interviews were analyzed by means of the digital program NVivo, which helped distinguish and systematize contents regarding the cases' characteristics and innovativeness. In this article, the results from the interviews provide the main part of the quotes presented in the subsequent section.

The presented study required no formal ethical review, since it concerns none of the application areas regulated in the Swedish Law of Ethical Review. It does however follow the ethical regulations and guidelines provided by Swedish law, the Swedish Ethical Review Authority and the guide on good research practice issued by The Swedish Research Council (2017). In regard to these regulations and guidelines, the presented study did not include collection, processing or distribution of any sensitive personal data regarding ethnicity, religion, health, sexuality, political view, or trade union membership that can be traced to a single individual. Non-sensitive personal data, such as the informants' names, titles, and contact information, was processed lawfully in line with The European Union's General Data Protection Regulation (GDPR). All informants were informed about the study's purpose and design, and their voluntary participation. The interviewees also signed letters of consent and their personal identities were anonymized in the data processing and results dissemination.

\section{Results}

This section presents the empirical results from the mapping, divided into three main themes distinguished in the data analysis: providing and preparing work opportunities, individualistic and holistic approaches, and managing work inclusion.

\section{Providing and preparing work opportunities}

The mapped cases encompass various measures for tackling work-related societal challenges of unemployment, poverty, segregation, and ill-health. These can be categorized 


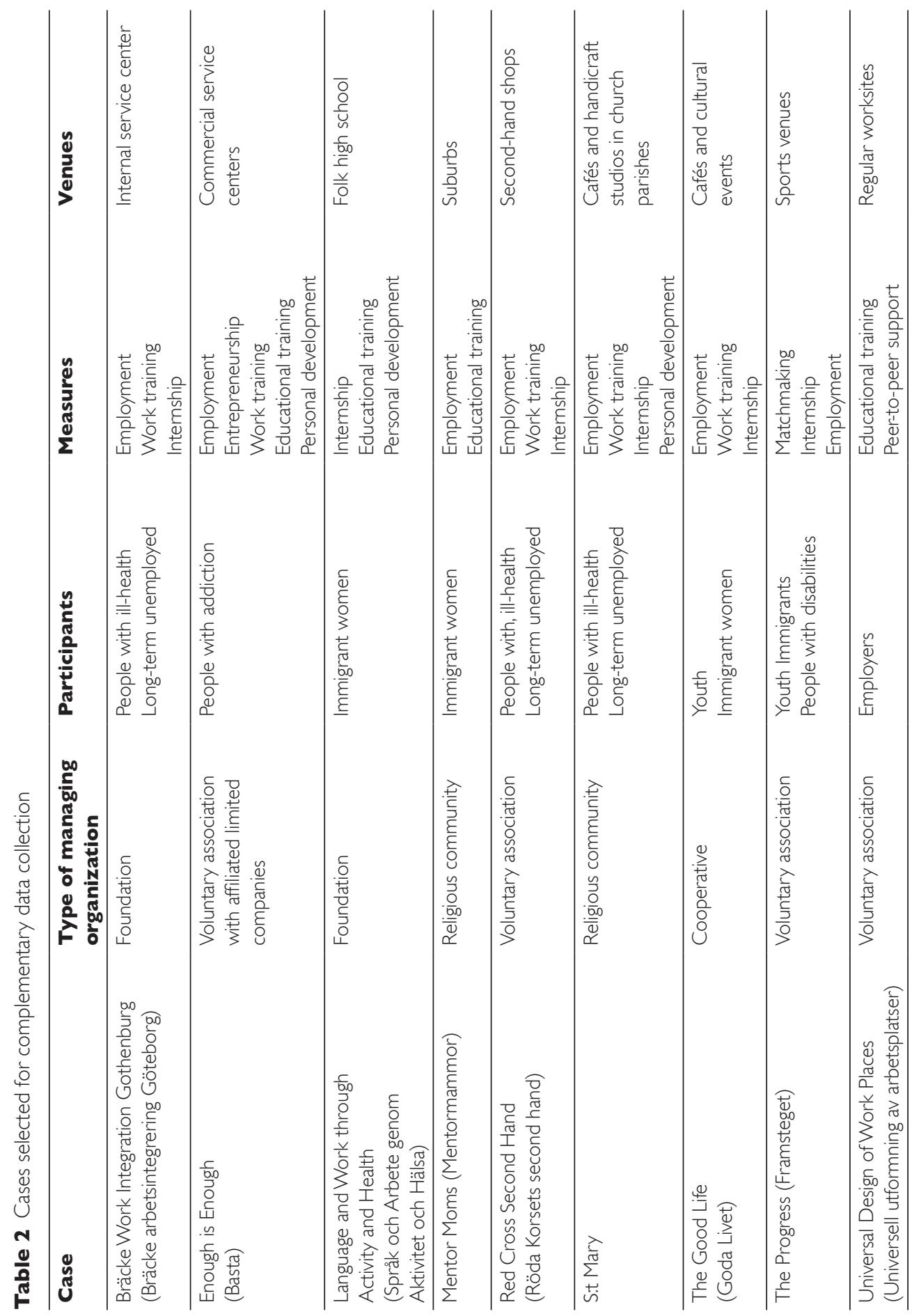


into two main types of measures: measures for providing actual work opportunities and measures for preparing work opportunities, described in more detail below.

Recurrent measures for providing work opportunities in the cases are employment, entrepreneurship, and volunteering. Employment opportunities are offered either on a short-term or long-term basis. In the cases of Flash Jobs (Blixtjobb) and Enough is Enough (Basta), people with addiction are offered long-term employment at commercial service centers that trade services in carpentry, gardening, administration, etc. In the latter case, the need for long-term employment opportunities is described in the following manner:

\begin{abstract}
Many are faithful to the established systems - all the projects that are invented, where only internships are provided without promoting the participants' right to proper educational training, employment or to be taken seriously. There must be a faith in their potential to succeed under the right circumstances. I have been very critical of other efforts that only circulate people (between temporary employment programs). (Interview Enough is Enough, 1 June 2020)
\end{abstract}

Other cases offer short-term employment as a steppingstone for ensuing work elsewhere in the labor market. That is, for example, the case in Common Future (Framtid Tillsammans), where a sports association mediates and supervises temporary employment in a municipality for immigrants, elderly, people with disabilities and others who belong to the 'prioritized groups' appointed by The Swedish Public Employment Service. It is also the case in The Red Cross Second Hand, where people with reduced working ability are offered temporary employment, work training and internship in a national chain of second-hand shops:

We have talked a lot about the rehab issue, how we should handle people with (...) wage subsidies (...). We should not primarily regard them as a temporary workforce, but (...) (also consider) their work rehabilitation (...) We may have them as employees for a few years and then they proceed to other employers, in order for them to develop and not get stuck with us. (Interview The Red Cross Second Hand, 5 June 2020)

Some cases provide work opportunities through entrepreneurship, often by involving the participants as co-managers in social enterprises, which pursue commercial trade as a means to achieve social aims. Some of these constitute WISE, in the sense that they specifically aim at work integration. This is, for example, the case in The Yalla Staircase (Yalla Trappan) where immigrant women are co-managers in a WISE that offers commercial services in catering, couture, cleaning, etc. Another example is Street Business that is a WISE that enables homeless people to support themselves through street trading, guided tours, urban farming, etc. Volunteering is offered as a work opportunity in some of the cases, for example in The Meaning of the Association (Meningen med föreningen) where immigrants are matched with TSOs in need of volunteers. Another example is The Disability Mediation Service (Funkisförmedlingen), which mediates volunteering and other work opportunities for people with various types of disabilities.

Recurrent measures for preparing work opportunities in the cases are work training, internship, matchmaking, mentorship, guidance, educational training, and 
personal development. Work training and internship are offered in several cases, which means that the participants temporarily can try a profession or a worksite. This is, for example, the case in S:t Mary where internship and work training are offered to people with reduced working ability at cafés and handicraft studios designated for that purpose, as part of local church parishes. Matchmaking is another recurrent measure, where participants are matched with employers in order to find and create new work opportunities. This is the case in The Progress (Framsteget) where a sports association matches youth with local employers:

We work very actively to channel our youth (...) to summer jobs and other (work opportunities). Right now, I have found two jobs (...) at the integration unit (of the municipality) to organize their archives. But I am also in contact with four private companies where I would like find some openings. (Interview The Progress, 5 March 2020)

Some cases offer mentorship where established professionals help open doors to the labor market for the participants in various professional domains. This is, for example, the case in Colleague to Colleague (Kollega till kollega) and The Art of Participating (Konsten att delta) where immigrant journalists and immigrant artists, respectively, are brought together with Swedish professionals in these areas. Educational training is another recurrent measure in the cases, in order to better match the participants' competences with current employer needs. Several cases use educational practices from the Swedish tradition of popular adult education (folkbildning), ${ }^{8}$ characterized by voluntary and mutual learning of practical and theoretical skills based on the participants' own needs and experiences. One example is Language and Work through Activity and Health (Språk och Arbete genom Aktivitet och Hälsa) where a folk high school offers workoriented language-training for immigrant women, by using drama-based pedagogy:

We had a drama teacher (...) who worked with the group (...) in order to make the participants relax and (...) to spark their language learning. It was very appreciated by the participants (...) and the managers noticed that the participants became braver and developed their language skills. That was quite cool. (Interview Language and Work through Activity and Health, 28 April 2020)

Several cases use measures for preparing work opportunities as a springboard for providing work opportunities in their own organizations and operations. This is particularly common among sports associations, as in the case of Swim Sports for All (Simidrott för alla) where a national swimming association offers educational training for immigrants to become swimming instructors and ensuing employment or volunteering opportunities in that capacity in their affiliated local associations. It is also common among WISE, as in Enough is Enough, where people with addiction are offered long-term work opportunities after taking part in their rehabilitation program:

We offer a one-year work-oriented addiction rehabilitation. Work-oriented means that a large part of the rehabilitation takes place at (our) worksites, through real entrepreneurship (...) The unique thing about Enough is Enough is that you have the opportunity to stay (here) after completing the rehabilitation and be involved in running the social enterprise. (Enough is Enough's official website, ${ }^{9}$ authors' translation) 


\section{Individualistic and holistic approaches}

The mapped cases address various groups of participants, perceived as disadvantaged in regard to the regular labor market, due to their age, gender, origin, disability, health status, etc. The case of Dynamo invites, for example, immigrant youth and youth with mental illhealth to co-produce concerts, exhibitions, movies, and literature at a cultural and social center. The case of Mentor Moms (Mentormammor) offers, in turn, educational training and employment for immigrant women as mentors for younger immigrant women:

It is both that the (immigrant) women often remain in the home to such great extent, wherein there is a lack of gender equality. At the same time, as a woman, you have your status in the home, unlike the man. But of course, you cannot get stuck in that, and (...) in order to become part of the Swedish society, you have to overcome that. That is what we try to contribute to. (Interview Mentor Moms, 2 June 2020)

Several cases underline the need to properly understand and address the participants' needs and preconditions. For example, the case of The Disability Mediation Service describes themselves as a unique complement to The Swedish Public Employment Service, since their operations are run by people who themselves have disabilities and thus have a good understanding and a great commitment to support their peers. ${ }^{10}$ The creation of Enough is Enough was also based on the participants' own needs:

There was always a bottom-up perspective and a need that came from the participants which we created Enough is Enough based upon (...) That has been a prerequisite for being innovative - you cannot solve anything by guessing or assuming. Then it is easy to end up in traditional solutions or in the wrong tracks. (You must be) very, very close to the target group, I would say. (Interview Enough is Enough, 1 June 2020)

In order to properly address the participants' actual needs, several cases combine an individualistic and holistic approach. The individualistic approach means that measures are tailored to each beneficiary's needs and preconditions. This is partly achieved through sheltered or supported employment, with adapted work tasks and working conditions. The case of Activa offers, for example, internship and work training for people with disabilities or mental ill-health at both their own sheltered worksites and other employers' regular worksites. The holistic approach means that the measures consider the individual's whole life situation. In the case of The Disability Mediation Service, this approach is described in the following manner:

The Disability Mediation Service takes the individual's whole life situation into account and realizes that all pieces are connected. We see that the support we need to provide is not always just about finding work in the regular labor market. There are so many other parts of a life situation that may also need to be worked on for them to get ready for work. (The Disability Mediation Service's official website, ${ }^{11}$ authors' translation)

The participants' needs are also addressed through personal development as a measure for preparing work opportunities. This aims to improve their self-awareness and 
self-esteem, in regard to work and self-provision. The case of IT-Guide offers, for example, personal development for immigrant youth by employing them at internet cafés where they make use of their digital skills to help elderly get acquainted with computers, smart phones, etc. Another example is S:t Mary, which aims to offer meaningful work, work pride, and work community:

That is sort of the basis (...) inclusion for real. And then you can say: "Who's definition (of inclusion) applies?" There you sort of have to elaborate an independent position where you both consider the public authorities' and (the project) funders' perspectives but also have your own an independent position on that matter. So yes, getting closer to work is definitely a kind of inclusion (...) but it is not the only criterion for inclusion. You can grow as a human being and break your isolation and live a satisfactory life without getting a real job. (Interview S:t Mary, 9 June 2020)

The organizations' pre-existing venues and activity areas are in several cases used as a resource to identify and address needs of improved work inclusion. This includes, for example, their activity areas of sports, culture, social services, and adult education. It also includes their venues of sports centers, folk high schools, church parishes, secondhand shops, handicraft and seamstress studios, as well as service centers, social centers, and cultural centers. The cases of The Couture Collective (Sömnadskollektivet) and Strong Women Seamstress Studio (Starka kvinnor syateljé) offer, for example, work opportunities for immigrant women at seamstress studios. The case of The Progress makes, in turn, use of their sports venues and activities for identifying and offering employment to youth:

We have identified several of the youth leaders ourselves. They have previously been participants in our activities and are now leaders (...) It is so cool that we have leaders today who participated (...) as youngsters and now lead the activities themselves when they are older. Our fundamental idea is to identify these leaders so that they can lead both youth and adults in our activities. (Interview The Progress, 5 March 2020)

\section{Managing work inclusion}

The mapped cases are managed in various manners, in regard to their type of managing TSO, funding sources, and stakeholder alliances. A wide range of TSO types are represented among those managing the cases, including voluntary associations, cooperatives, foundations, and religious communities. For example, the case of IM Startup Hub, which offers work-oriented guidance, educational training and personal development to immigrants, is managed by a voluntary association that describes themselves as 'a development organization that fights for a humane world free from poverty and exclusion'. ${ }^{12}$ The case of Bräcke Work Integration Gothenburg (Bräcke arbetsintegrering Göteborg), which offers work training, internship and employment for people with ill-health and long-term unemployed at an internal service center, is in turn managed by a foundation which has provided care and welfare services in Sweden for almost 100 years. The case of The Good Life (Goda Livet), which offers employment at cafés and cultural events 
for youth, immigrant women and people with disabilities, is managed by a cooperative. They describe the motivation for their choice of organization type in the following way:

The initial idea was $(\ldots)$ to form a voluntary association. But the labor market focus made it more appropriate to emphasize the economic part and form a cooperative instead. (Interview The Good Life, 5 May 2020)

The quote suggests that the orientation and funding of the operations may be related to the choice of organization type. Nevertheless, the mapping in large shows that commercial activities with work-integration purposes are pursued by all types of TSOs. The mapping also demonstrates that cooperatives do not provide work opportunities to any greater extent than other TSO types, among the cases. The main perceivable difference is instead between cases pursued as projects and those pursued as permanent establishments. The temporary nature of projects does not, per se, allow for long-term employment in the same way as permanent operations do. On the other hand, several of the cases have evolved from projects to permanent establishments over time. For example, the case of S:t Mary was initiated through a series of projects that later led to permanent establishments. The challenges in this transition are described in the following manner:

When I started and said that we would start a S:t Mary, it was probably no one who (thought anything other than): “Ah, here comes another project" (...) When we then renovated a house and initiated a handicraft studio and a café, it became very public (...) That caused quite some turbulence: "What, have we decided this?", "Should it be this way?”, "Is this what we should do?” (...) And when I then started to work for (...) making it permanent (...) and connect it with the regular parish operations, people seemed to wake up (and say): "Oh, is this something we should keep?" (Interview S:t Mary, 26 May 2020)

The quote reflects the pivotal role of funding for the mapped cases' ability to initiate and establish new operations for work inclusion. In several of the cases, project funding from public authorities on the national, regional, or local levels is used for developing, testing, and evaluating potential measures during a limited period of time. The project funding is often earmarked for purposes in line with public interests and often apply innovativeness as an eligibility criterion, in the sense that the funded measures must be novel in some sense. Some of the cases also receive other types of time-limited and earmarked subsidies for their work inclusion efforts, directed towards certain groups of participants or TSO types. For example, study associations regularly receive temporary subsidies from the Swedish government for helping improve work inclusion among youth, immigrant women, and others. ${ }^{13}$

The funding of permanent establishments in the mapped cases is based on a combination of commercial trade, public subsidies, and internal resources. Commercial trade means that goods or services are sold to individual consumers or to other organizations - including public authorities - on a commercial or contractual basis. In the cases that are managed in the form of WISE, the trade is primarily pursued as a means to achieve work inclusion. Public subsidies refer in this context to Swedish employment programs that compensate TSOs for providing subsidized or supported employment for people 
with reduced working ability. Internal resources mean, in turn, that the TSOs' existing financial or human capital is utilized, including funds, infrastructure, knowledge, employees, volunteers, etc. In The Red Cross Second Hand, there is a perceived rivalry between volunteering, internship, and employment due to public funding:

(The second-hand shops) should be run by volunteers who work for free and dedicate their time to help out in a store. At the same time, the local association takes in people with internships via The Swedish Public Employment Service and The Swedish Prison and Probation Service (Kriminalvården) in the operation, who may outrival the volunteers. They also employ people in order to maintain high quality - it is such a great responsibility. The number of employees increases more and more for managing our concept, since it is too complicated (...) It is easy nowadays to bring in external manpower since you receive public subsidies for that. (Interview The Red Cross Second Hand, 4 June 2020)

The benefits and challenges of different funding sources are also reflected in the mapped cases' mobilization and alliances with stakeholders. Most cases involve other organizations from the third, public or private sector to some extent, as a way to cope with the cross-sectorial character of work-related societal challenges. There are, for example, recurrent alliances between TSOs and public authorities, for example, municipalities and The Swedish Public Employment Service, based in the latter's formal responsibilities for Sweden's employment programs. These alliances are sometimes formalized and funded through contracts or partnerships in the mapped cases. For example, the case of Woman in Botkyrka (Kvinna $i$ Botkyrka), which offers work-oriented matchmaking, guidance, and personal development for immigrant women, is managed and funded through an IOP between a study association, a folk high school, a municipality, and The Swedish Public Employment Service. Another example is The Leisure Bank (Fritidsbanken), which offers work opportunities for people with reduced working ability at non-profit libraries for sports and outdoor equipment, through partnerships between municipalities, sports associations, religious communities, and other stakeholders.

Alliances between TSOs and private sector actors in the mapped cases mainly take the form of relations and routes for channeling participants to work opportunities in companies, as described above. In some cases, companies are involved through crosssector partnerships. This is for example the case in Universal Design of Work Places (Universell utformning av arbetsplatser), which offers educational training and guidance in designing inclusive workplaces for all, including those being disadvantaged due to disabilities, ill-health, origin, or other factors. This is achieved through an alliance between trade unions, advocacy associations, and employers from the private and public sectors:

All these different collaborations that exist today are usually sectoral and we are crosssectorial (...) We cherish this social innovation because I think it is beneficial with crosssectorial learning (...) If we become too segmented in employers, trade unions (and) public authorities, then we are back in the regular drainpipe model. If we can avoid that (...) then I think we can keep this energy and benefit from cooperating with each other (...) I feel optimistic, even if it's a challenge. (Interview Universal Design of Work Places, 20 February 2020) 


\section{Discussion}

The mapped cases encompass a variety of efforts for work inclusion that are innovative both in the sense that they are new to the managing organizations and their target groups, and in that they provide alternative or complementary ways to perceive and promote work inclusion. The social innovativeness in the cases' aims, means, and compensating abilities is discussed in more detail below.

\section{Socially innovative aims}

The results show that the mapped cases are socially innovative in their aims, in the sense that they strive to tackle work-related societal challenges of unemployment, poverty, segregation, and ill-health, in line with the social needs orientation of many TSOs (Anheier et al. 2019; Lindberg 2021). More precisely, the mapped cases strive for improved work inclusion across a sliding scale, illustrated in Figure 1. It ranges from improved self-esteem in regard to work and self-provision at the one end, to obtaining long-term employment, at the other end. In between these end poles, there are aims of getting closer to the working life in terms of improved skills, abilities or orientation, as well as obtaining short-term employment or other types of occupation, such as volunteering and entrepreneurship.

Figure I Socially innovative aims for work inclusion.

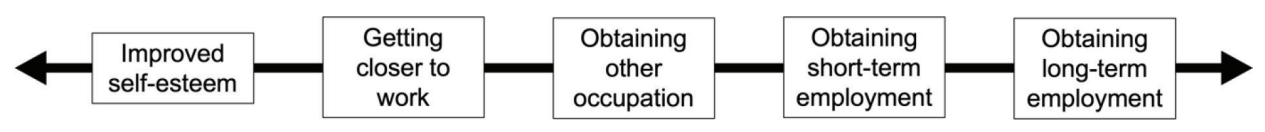

By encompassing the whole scale, the mapped cases promote a broadened view on what improved work inclusion may imply, where obtaining paid work is just one of several alternative aims. An innovative contribution of Swedish TSOs to work inclusion is thereby an alternative or complementary way to perceive how work-related societal challenges should be tackled in regard to 'the work strategy' of Swedish labor market policies, which prescribes a more or less mandatory participation in paid labor for all adults (Wikström \& Ahnlund 2018). This contribution may be derived from the TSOs' freestanding position as a 'third sector' in society which enables them to be voice-bearers for disadvantaged groups and advocacy actors for citizen interests, alongside their role as welfare service providers (Anheier et al. 2019, Lindberg 2021). However, the results also reveal that the social innovativeness in the cases' aims may be restricted by the earmarking of their public subsidies (Lindberg 2021; Lindberg et al. 2018), since it incentivizes TSOs to comply with the overarching aims of Swedish labor market policies to some extent.

\section{Socially innovative means}

The results further show that the mapped cases are socially innovative in their means, in the sense that they creatively make use of various measures, venues, management 
strategies, and stakeholder alliances to fulfil their purposes. This is in line with the new social relations, practices and structures that characterize social innovation (Anheier et al. 2019; Lindberg 2021). It also reflects the diversity that characterizes the Nordic third sector in general, with multifaceted organization types, activity areas and engagement forms (Henriksen et al. 2019; von Essen \& Svedberg 2020). More precisely, the social means of the cases are manifested in their combinations of measures for providing actual work opportunities - that is, employment, entrepreneurship, and volunteering - with measures for preparing work opportunities - that is, work training, internship, matchmaking, mentorship, guidance, educational training, and personal development, illustrated in Figure 2.

Figure 2 Socially innovative means for work inclusion.

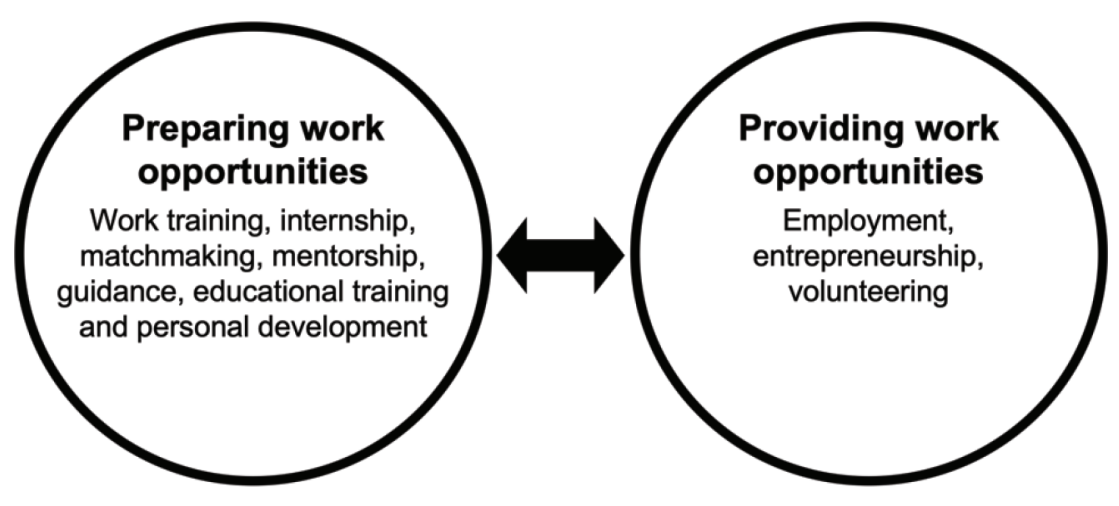

By combining measures for providing and preparing work opportunities, the mapped cases advocate a broader approach to work inclusion than employment opportunities only. They thus innovatively contribute with an alternative or complementary way to promote wellbeing, inclusion and empowerment in regard to 'the work first approach' of Swedish labor market policies, where paid work is seen as the principal way to tackle several societal challenges (Wikström \& Ahnlund 2018). The reconciliation of the TSOs' roles as freestanding voice-bearers and contracted welfare service providers (Anheier et al. 2019; Lindberg 2021) may incentivize them to consider both bottom-up and top-down approaches to work inclusion. Nevertheless, the results show that the social innovativeness in the cases' means may be restricted by the terms for their offered employment programs, which are per se based on the work first approach of Swedish labor market policies.

The mapped cases also make innovative use of individualistic and holistic approaches to properly understand and address the varying needs and preconditions of the participants. This helps them handle the variety that characterize those perceived to be particularly disadvantaged in regard to the regular labor market (Gustafsson et al. 2018; Hobbins 2016; Wikström \& Ahnlund 2018). These approaches are enhanced by the use of TSOs' pre-existing venues and activity areas to identify and address needs 
of improved work inclusion. It also serves to balance parallel understandings of work inclusion as a matter of the individual's own experiences of being included, as well as a matter of actual treatment in organizations and society (Brimhall 2019; Lysaght et al. 2012). The cases thus innovatively contribute with an alternative or complementary way to promote work inclusion in regard to the perceived shift in Swedish labor market policies from explaining unemployment by 'lack of employment' in organizations and society to 'lack of employability' among individuals (Wikström \& Ahnlund 2018). The cases' ability to empower the participants may however be restricted by their public subsidies being earmarked for measures and target groups that conform with public interests (Lindberg 2021; Lindberg et al. 2018).

\section{Compensating for sectorial failures}

The variation of TSOs that manage the cases - including voluntary associations, cooperatives, foundations, and religious communities - reflects the organizational diversity of the Nordic third sector in general (Henriksen et al. 2019; von Essen \& Svedberg 2020). This diversity is also reflected in the wide range of venues and activity areas that several of the cases make use of as arenas for promoting work inclusion, including sports centers, church parishes, second-hand shops, handicraft and seamstress studios, etc. It is further reflected in the cases' varied engagement forms of employment, volunteering, entrepreneurship, etc. The cases' funding sources are also diverse, with public subsidies, commercial trade, and internal resources, similar to TSOs' diverse business models in general (Lindberg 2021). The multi-actor mobilization through cross-sector partnerships, which is common in social innovation for work inclusion (Leca et al. 2019; Oeij et al. 2018), is reflected in the mapped cases' stakeholder alliances with public, private and third sector actors. This diversity of organization, funding and alliances in the cases may contribute with an alternative or complementary way to promote work inclusion in regard to 'government failure' and 'market failure' in the welfare domain (Steinberg 2006). Therefore, the cases' diversity may make TSOs better at addressing heterogenous preferences of work inclusion than public sector actors. Furthermore, it may make TSOs better at signaling trustworthiness than private sector actors by putting social interests over profiteering interests when promoting work inclusion.

The mapped cases, nevertheless, expose examples of 'voluntary failure' as well, similar to previous studies (Steinberg 2006). Several cases fail, for example, to make better use of TSOs' diverse venues and activity areas to provide long-term employment for their participants. Instead, they tend to channel participants to work opportunities among other employers, either instantly or after providing short-term measures. This may, in turn, aggravate the fact that many cases fail to make better use of their work inclusion measures to improve the diversity among their own regular workforce that is generally homogenous (Jutterström et al. 2018; Unionen 2016). Many cases also fail to make better use of volunteering to promote work inclusion, despite the tradition among many TSOs of engaging both employees and volunteers in social innovation (de Wit et al. 2019). These failures seem to correspond with an understanding of work inclusion that primarily regards the community outside their own organizations, rather than employees inside their organizations (Brimhall 2019; Fujimoto et al. 2019). 


\section{Conclusion}

Returning to the media debate regarding the shortcomings of the Swedish state-owned company Samhall to fulfil its work inclusive mission, the presented study exposes how organizations in the third sector of the Swedish society aspire to better promote work inclusion among those who need it the most. In contrast to the perceived problems with 'cream skimming' in Samhall, the mapped cases make use of TSOs' social needs orientation to identify and address unmet and neglected needs of improved social inclusion among those who are increasingly disqualified from employment and self-provision due to sharpened requirements and conditions on the Nordic labor market - even at Samhall. Since traditional employment services are considered insufficient for promoting work inclusion among youth, immigrants, people with disabilities, and other disadvantaged groups, the mapped cases provide alternative or complementary solutions for improving their wellbeing, inclusion, and empowerment. Their innovative contributions to this field are distinguished in the form of their socially innovative aims which strive for improved work inclusion across a sliding scale from improved self-esteem in regard to work and self-provision to obtaining long-term employment. It is also distinguished in the form of their socially innovative means, with combined measures for providing and preparing work opportunities as well as combined individualistic and holistic approaches.

These contributions highlight the issue at heart of the cited media debate, regarding which societal actors are best placed to help those most stricken by work-related societal challenges of unemployment, poverty, ill-health, and segregation. While Sweden's current labor market policies seem to transfer the responsibility for inclusion from the society to the individual, the mapped cases strive to better balance the division of responsibilities both between individuals and the society, and between actors from different societal sectors. By combining their roles of voice-bearers, advocacy actors, and service providers, the engaged TSOs are able to push the limits of the Nordic welfare model, where public authorities traditionally have been the main providers of welfare services, while TSOs mainly have been ascribed a complementary role.

The initially cited claim that TSOs outperform other sectors in social innovation is nevertheless more nuanced when it comes to labor market renewal. The ability of the mapped cases to compensate for government and market failures in regard to work inclusion seems to be restricted by the earmarked terms for their public subsidies that incentivize them to comply with the aims and means of Swedish labor market policies to some extent. Their compensating ability also seems to be restricted by voluntary failures, in that they fail to make better use of their multifaceted venues, activities and alliances to provide long-term employment and volunteering opportunities in their own organizations. As a consequence, they also seem to fail at making better use of their work inclusion efforts to improve their own workforce diversity.

These conclusions call for further scrutiny among both policymakers and TSOs regarding how to better divide their responsibilities for work inclusion among those in most need. As of now, the TSOs seem to take greater responsibility than actually allowed for in Swedish employment programs, in order to compensate for government and market failures in this domain. And since public authorities seem to be unable to maintain their traditional role as main providers of welfare services, there is a need to adapt public subsidies to better fit the innovative efforts carried out by TSOs. In order to make use of their socially innovative aims and means to tackle work-related 
societal challenges, there is also a need for revising 'the work strategy' and 'the work first approach' as guiding principles for Swedish labor market policies. This might help to turn back from explaining unemployment by 'lack of employability' among individuals to primarily treating it as a matter of 'lack of employment' in organizations and society, where work opportunities are adapted to the needs and prerequisites among those most stricken by these challenges.

\section{Acknowledgements}

The presented study was carried out as part of a research project funded by the Swedish

Research Council for Health, Working Life and Welfare (Forte), dnr 2019-01238.

\section{References}

Alasoini, T. (2011). Workplace Development as Part of Broad-based Innovation Policy, Nordic Journal of Working Life Studies 1(1): 23-43. doi: https://doi.org/10.19154/njwls. v1i1.2334.

Andreassen, T. A., Breit, E., Saltkjel, T. (2020). Research approaches to networked employment services, Social Policy \& Administration. doi: https://doi.org/10.1111/spol.12597.

Anheier, H. K., Krlev, G., Mildenberger, G. (Eds.) (2019). Social Innovation: Comparative Perspectives, New York: Routledge. doi: https://doi.org/10.4324/9781315158020.

Bakker, A. B., Gherardi, S., Grote, G., Lansbury, R., Pawlowsky, P., Roe, R. A. (2015). Swedish Research on Work Organization 2007-2013, Stockholm: Forte.

Boulus-Rødje, N. (2019). Welfare-to-work Policies Meeting Complex Realities of Unemployed Citizens, Nordic Journal of Working Life Studies 9(2): 47-65. doi: https://doi. org/10.18291/njwls.v9i2.114800.

Bredgaard, T., \& Thomsen, T. (2018). Integration of Refugees on the Danish Labor Market, Nordic Journal of Working Life Studies 8(4): 7-26. doi: https://doi.org/10.18291/njwls. v8is4.111161.

Brimhall, K. C. (2019). Are We Innovative? Increasing Perceptions of Nonprofit Innovation Through Leadership, Inclusion and Commitment, Review of Public Personnel Administration 41(1): 3-24. doi: https://doi.org/10.1177/0734371x19857455.

Butzin, A. \& Terstriep, J. (2018). Actors and Roles in Social Innovation. In Howaldt, J., Kaletka, C., Schröder, A., Zirngiebl, M. (Eds.), Atlas of Social Innovation - New Practices for a Better Future, Dortmund: TU Dortmund University, pp. 78-81.

de Wit, A., Mensink, W., Einarsson, T., Bekkers, R. (2019). Beyond Service Production: Volunteering for Social Innovation, Nonprofit and Voluntary Sector Quarterly 48(2): 52-71. doi: https://doi.org/10.1177/0899764017734651.

Fujimoto,Y.,Azmat,F.,Subramaniam,N.(2019).Creating Community-Inclusive Organizations, Business and Society 58(4): 712-748. doi: https://doi.org/10.1177/0007650316680060.

Gustafsson, J., Peralta, J., Danermark, B. (2018). Supported Employment and Social Inclusion experiences of Workers with Disabilities in Wage Subsidized Employment in Sweden, Scandinavian Journal of Disability Research, 20(1): 26-36. doi: http://doi.org/10.16993/sjdr.36.

Henriksen, L. S., Strømsnes, K., Svedberg, L. (Eds.) (2019). Civic engagement in Scandinavia, Cham: Springer. doi: https://doi.org/10.1007/978-3-319-98717-0.

Hobbins, J. (2016). Young long-term unemployed and the individualization of responsibility, Nordic Journal of Working Life Studies 6(2): 43-59. doi: http://dx.doi.org/10.19154/ njwls.v6i2.4971. 
Hvenmark, J. (2013). Business as usual? On managerialization and the adoption of the Balanced Scorecard in a democratically governed civil society organization, Administrative Theory \& Praxis 35(2): 224-248. doi: https://doi.org/10.2753/ATP1084-1806350203.

Hvenmark, J. (2016). Ideology, practice, and process? A review of the concept of managerialism in civil society studies, Voluntas 27(6): 2833-2859. doi: https://doi.org/10.1007/ s11266-015-9605-z.

Hvid, H., Bergholm, T., Gonäs, L., Juul, I., Kamp, A., Karlsson, J., Kasvio, A., Klemsdal, L., Salomon, R. H., Skorstad, E. J. (2011). Nordic Working Life Research - Continuity and Renewal, Nordic Journal of Working Life Studies 1(1): 3-21. doi: https://doi.org/ 10.19154/njwls.v1i1.2333.

Jutterström, M., Segnestam Larsson, O., Zetterström, S., Hedlin, D. (2018). Anställd i det svenska civilsamhället (Employed in the Swedish civil society), Stockholm: KFO, IDEA, Arbetsgivaralliansen.

Kamp, A., Klemsdal, L., Gonäs, L. (2013). Working in the Public Sector - Introduction to the Thematic Issue, Nordic Journal of Working Life Studies 3(2): 1-8. doi: https://doi. org/10.19154/njwls.v3i2.2547.

Kapoor, K., Weerakkody, V., Schroeder, A. (2018). Social innovations for social cohesion in Western Europe, Innovation: The European Journal of Social Science Research 31(2): 189-203. doi: https://doi.org/10.1080/13511610.2017.1419336.

Leca, B., Sandford, S., Cognat, A. S., Pache, A.-C., Mato-Santiso, V., Hyánek, V., Krlev, G. (2019). Cross-Sector Partnerships Cross-Sector Partnerships - A Social Innovation in the European Work Integration Sector. In Anheier, H. K., Krlev, G. \& Mildenberger, G. (Eds.), Social innovation - comparative perspectives, New York: Routledge, pp. 201-223.

Lindberg, M. (2021). Social innovation i civilsamhällets organisationer (Social innovation in civil society organizations), Örebro: Entreprenörskapsforum.

Lindberg, M. \& Nahnfeldt, C. (2017a). Idealistic incentives in non-governmental organization innovativeness, Prometheus - Critical Studies in Innovation 35(2): 97-110. doi: https://doi.org/10.1080/08109028.2017.1396751.

Lindberg, M. \& Nahnfeldt, C. (2017b). Idéburen innovation (Idealistic innovation), Stockholm: Idealistas.

Lindberg, M., Tengqvist, A., Sevedag, V. (2018). Social innovation i Europeiska socialfonden (Social innovation in the European Social Fund), Stockholm: Forte and Svenska ESFrådet.

Lysaght, R., Ouellette-Kuntz, H., Lin, C.-J. (2012). Untapped potential: Perspectives on the employment of people with intellectual disability, Work 41: 409-422. doi: https://doi. org/10.3233/wor-2012-1318.

Meeuwisse, A. (2008). Organizational innovation in the Swedish welfare state, Critical Social Policy 28(2): 187-210. doi: https://doi.org/10.1177/0261018307087989.

Oeij, P. Dhondt, S., van der Torre, W. (2018). Linking Practice Fields of Social Innovations in the Domain of Employment. In Howaldt, J., Kaletka, C., Schröder, A. \& Zirngiebl, M. (Eds.), Atlas of Social Innovation - New Practices for a Better Future, Dortmund: TU Dortmund University, pp. 173-175.

Selander, K. \& Ruuskanen, P. (2016). Why do Third Sector Employees Intend to Remain or Leave their Workplace? Nordic Journal of Working Life Studies 6(2): 81-100. doi: https://doi.org/10.19154/njwls.v6i2.4967.

Skedinger, P. \& Widerstedt, B. (2007). Cream skimming in employment programmes for the disabled? International Journal of Manpower 28(8): 694-714. doi: https://doi. org/10.1108/01437720710835174.

Steinberg, R. (2006). Economic Theories of Nonprofit Organizations. In W. W. Powell \& R. Steinberg (Eds.), The nonprofit sector: A research handbook, New Haven: Yale University Press, pp. 117-139. 
The Swedish Research Council (2017). God forskningssed (Good research practice), Stockholm: Vetenskapsrådet.

Unionen (2016). Anställd i civilsamhället - ett kall eller vanligt kneg? (Employed in the civil society - a calling or an ordinary job?), Stockholm: Unionen.

von Essen, J. \& Svedberg, L. (Eds.) (2020). Medborgerligt engagemang i Sverige 1992-2019 (Citizen engagement in Sweden 1992-2019), Stockholm: Ersta Sköndal Bräcke högskola.

Wijkström, F. \& Zimmer, A. (Eds.) (2011). Nordic Civil Society at a Cross-Roads, BadenBaden: Nomos. doi: https://doi.org/10.5771/9783845231624.

Wikström, E. \& Ahnlund, P. (2018). Making Refugees Work? Individualized Work Strategies in the Swedish Refugee Settlement Program, Nordic Journal of Working Life Studies 8(4): 47-65. doi: https://doi.org/10.18291/njwls.v8is4.111157.

Yin, R. K. (2009). Case Study Research, London: SAGE.

\section{Notes}

${ }^{1}$ https://da.se/2021/04/unga-slas-ut-platsar-inte-pa-samhall, Retrieved 26 May 2021.

2 https://da.se/tema/sjuka-samhall, retrieved 26 May 2021.

3 https://www.svtplay.se/video/31029838/uppdrag-granskning/uppdrag-granskning-for-svagfor-samhall, retrieved 26 May 2021.

${ }^{4}$ WISE are organizations that pursue commercial trade as a means to create work opportunities for people who are disadvantaged in the regular labor market.

${ }^{5}$ A list of all mapped cases is available via https:/www.ltu.se/research/subjects/Industriell-design/ Forskningsprojekt/Innovativ-inkludering-i-den-ideella-sektorns-arbetsliv-1.188789?!=en

${ }^{6}$ Several participant groups can be included in a single case.

${ }^{7}$ Several measures can be included in a single case.

${ }^{8}$ https://www.folkuniversitetet.se/in-english/about-folkuniversitetet/what-is-folkbildning/, retrieved 5 June 2021.

${ }^{9}$ https://basta.se/, retrieved 8 June 2021.

${ }^{10} \mathrm{http}: / / w w w . f u n k i s f o r m e d l i n g e n . s e$, retrieved 5 June 2021.

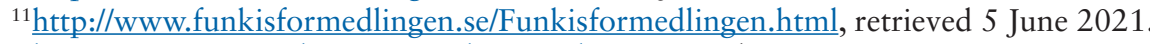

${ }^{12}$ https://www.imsweden.org/en/what-we-do/, retrieved 8 June 2021.

${ }^{13} \mathrm{https}$ ://www.folkbildningsradet.se/om-studieforbund/etablering-arbetsmarknadsatgarderoch-manskliga-rattigheter/, retrieved 7 June 2021. 